\title{
International criminal justice in an age of perpetual crisis
}

\author{
Joseph Powderly* \\ Leiden University, Grotius Centre for International Legal Studies, Kamerlingh Onnes Gebouw, 2311 ES Leiden \\ Email: j.c.powderly@law.leidenuniv.nl
}

Even from the abyss of horror in which we try to feel our way today, half blind, our hearts distraught and shattered, I look up again and again to the ancient constellations that shone on my childhood, comforting myself with the inherited confidence that, some day, this relapse will appear only an interval in the eternal rhythm of progress onward and upward.

Stefan Zweig, The World of Yesterday: Memoirs of a European ${ }^{1}$

\section{Introduction}

It is difficult to pinpoint the exact moment at which international criminal justice ceased to be a flourishing liberal cosmopolitan, progressive project. ${ }^{2}$ Perhaps it remains so, but with hindsight, to advocate for it on such terms seems incomprehensibly naive; a totem of an age of idealistic innocence, a relic of the world of yesterday. ${ }^{3}$ The pervading, palpable sense of 'crisis' at the heart of the international criminal justice project has long since ended the cosmopolitan reverie and has widened the space within international criminal scholarship for perspectives advocating for much needed realism, pragmatism, and an increased commitment to critique. ${ }^{4}$ However, it would appear that pervasive crisis may be resulting in a sense of 'crisis fatigue'. It is important at this point in time to consider the potential implications of this 'crisis fatigue' on both the international criminal justice project generally and international criminal scholarship in particular.

${ }^{\star}$ Editorial Board, Associate Professor of Public International Law, Grotius Centre for International Legal Studies, Leiden University. I am grateful to Sergey Vasiliev, Jens Iverson, Eric De Brabandere, and Ingo Venzke for their valuable insights and comments.

${ }^{1}$ S. Zweig, The World of Yesterday: Memoirs of a European (2009), at 3.

${ }^{2}$ For some background, see D. Robinson, 'A Cosmopolitan Liberal Account of International Criminal Law', (2013) 26 LJIL 127; B. Sander, 'International Criminal Justice as Progress: From Faith to Critique', in M. Bergsmo et al. (eds.), Historical Origins of International Criminal Law: Volume 4 (2015), 749; G. Simpson, 'The Conscience of Civilization and Its Discontents: A Counter-history of International Criminal Law', in P. Kastner (ed.), International Criminal Law in Context (2017), 9.

${ }^{3}$ See I. Tallgren, 'The Sensibility and Sense of International Criminal Law', (2002) 13 EJIL 561; D. Luban, 'After the Honeymoon: Reflections on the Current State of International Criminal Justice', (2013) 11 JICJ 505; G. Simpson, 'Linear Law: The History of International Criminal Law', in C. Schwöbel (ed.), Critical Approaches to International Criminal Law (2014), 159; J. Rabkin, 'Global Criminal Justice: An Idea Whose Time has Passed', (2005) 38 CILJ 753.

${ }^{4}$ The editorial contributions of my colleagues in the International Criminal Courts and Tribunals section of LJIL have reflected on this necessary evolution in international criminal scholarship. See C. Stahn, 'Between "Faith" and "Facts": By What Standards Should We Assess International Criminal Justice?', (2012) 25 LJIL 251; D. Jacobs, 'Sitting on the Wall, Looking In: Some Reflections on the Critique of International Criminal Law', (2015) 28 LJIL 1; S. Vasiliev, 'On Trajectories and Destinations of International Criminal Law Scholarship', (2015) 28 LJIL 701; E. van Sliedregt, 'International Criminal Law: Over-Studied and Underachieving?', (2016) 29 LJIL 1.

(c) Foundation of the Leiden Journal of International Law 2018 
For longer than it was reasonable to expect, international criminal justice's youthful immaturity and righteous optimism protected it from the worst of the inherent uncertainty and unpredictability of the international legal order. ${ }^{5}$ Not so long ago international criminal justice was the protégé of the international community; a golden child amongst several disappointing siblings and cousins. It was showered with praise and shielded from criticism, its needs were fulfilled irrespective of the financial burden that they imposed, careful attention was given to building its selfesteem, and it was reassured that it could be whatever it wanted to be; in short, it was given every opportunity in life by enthusiastic, loving parents.

However, all too predictably it would seem that such a sheltered, protective upbringing, while conducive for an idyllic childhood, has left it unprepared to deal effectively with the challenges of adulthood. Having fled the nest of the United Nations and taken up permanent residence in the International Criminal Court (ICC), it has struggled to find its footing in the big bad world. The child protégé has become overwhelmed by the burden of familial expectations; where once it could do no wrong in the eyes of its parents, now it seems it can get nothing right. ${ }^{6}$ Praise has turned to incessant criticism and occasional bullying, the pressures of financial self-sufficiency have frustrated its ambition, and despite its best efforts it is riddled with doubts and on the verge of burnout. It is plain for all to see that it is struggling with the immense responsibility that has been placed on its shoulders, and is in desperate need of a break, an intervention, for the pressure to be lifted; but despite cries for help, it is expected to stoically continue. For certain, parental support is not entirely absent and it retains a network of core friends, but ultimately it has to fight its own battles.

Today, at times it can seem that, wherever you look in international criminal justice, another crisis has been declared or is thought to be lurking over the horizon. ${ }^{7}$ This Editorial looks at the gradual replacement of international criminal justice's progress narrative with a narrative of crisis and discontentment. In particular, it reflects on the positive and negative impacts of 'crisis' on the evolution of sophisticated approaches to international criminal scholarship.

\section{Crisis and self-reflection}

The precarious state of international criminal justice's emotional well-being has not gone unnoticed, particularly in the pages of LJIL. ${ }^{8}$ It is fair to say that the critical turn in international criminal scholarship has been instrumental in exposing and diagnosing the neuroses of international criminal justice. ${ }^{9}$ As Frédéric Mégret has brilliantly shown, international criminal justice exists amidst an exhausting fog of complex anxieties ranging from the anxiety of birth and being, to the anxiety of demise and ultimately death. ${ }^{10}$ However, there is no causal link between the turn to critique and international criminal justice's existential angst; rather, as Mégret emphasizes, the turn to critique has merely pointed to something 'that is already intimately tormenting the discipline from within'. ${ }^{11}$

The distress may have been internalized, and be due to a host of internal factors, but it is impossible to ignore the external sources of torment which it has had to combat and endure in recent times. Conceiving of international criminal justice as existing in a state of barely concealed torment seems entirely in keeping with the troubling trajectory of the contemporary geopolitical landscape, and its consequent erosive impact on the liberal underpinnings of the international legal

\footnotetext{
${ }^{5}$ F. Mégret, 'The Anxieties of International Criminal Justice', (2016) 29 LJIL 197, at 197.

${ }^{6}$ See, for example, D. Robinson, 'Inescapable Dyads: Why the International Criminal Court Cannot Win', (2016) 29 LJIL 323.

${ }^{7}$ S. Vasiliev, 'The Crises and Critiques of International Criminal Justice', Draft Paper, ICC Scholars Forum 2018, The Hague, 15-16 June 2018. Copy on file with author.

${ }^{8}$ See, for example, D. Robinson, 'The Identity Crisis of International Criminal Law', (2008) 21 LJIL 925; see Robinson, supra note 7; 'A Cosmopolitan Liberal Account of International Criminal Law', (2013) 26 LJIL 127; see also Mégret, supra note 6.

${ }^{9}$ See Mégret, supra note 6, at 218.

${ }^{10}$ Ibid., at $199-200$.

${ }^{11}$ Ibid., at 219.
} 
order. From Trumpian unilateralism, isolationism and protectionism to Brexit, alongside the sinister global rise of exclusionary nationalism, inter-ethnic conflict, demagoguery and authoritarianism, we are confronted on a daily basis with the latest event heralding the crisis of world order. ${ }^{12} \mathrm{~A}$ product of the ubiquity of the crisis narrative across the international legal discourse has been the recognition of the urgent need for self-reflection about the position, function, and vulnerability of international law in times of crisis, or, as some have put it, in 'a dark time. ${ }^{13}$ It has also inspired reflections on the contingencies of international law; of what might have been. ${ }^{14}$

Significantly, the discourse has not shied away from examining whether international law is itself in a state of crisis and may be predominantly a part of the problem rather than the solution. ${ }^{15}$ It is not entirely irrational for the epistemic community to feel a pang of heightened anxiety in the face of current events, but fundamentally, it should not be forgotten that for good or for bad, international law has to a large extent been forged in the crucible of global crises. ${ }^{16}$ As Hilary Charlesworth so outspokenly put it: '[i]nternational lawyers revel in a good crisis. A crisis provides a focus for the development of the discipline and it also allows international lawyers the sense that their work is of immediate, intense relevance'. ${ }^{17}$

This is especially true of international criminal law, whose very existence is predicated on the purportedly urgent need of humanity to eradicate impunity for shocking acts committed in the context of past or ongoing crises. ${ }^{18}$ Moments of crisis can foretell the end of an era, inspire action, and provide the impetus for revolutionary change; ${ }^{19}$ international criminal justice is certainly a product of such revolutionary potential. Looking at the origins and evolution of the international criminal justice project, it is clear that for 70 years scholars have fetishized the nativity of the International Military Tribunal at Nuremberg as representing the humanizing moment of international law in the face of the inhumanity of global conflict. The gospel of the nativity scene at Nuremberg, endlessly recounted in scholarship, has come to symbolize the expressive potential of international law to respond to and emerge from epoch-defining crises, in a way that reboots humanity and the notion of world order. The authenticity of the nativity scene has been significantly reconsidered in recent times, with the acknowledgment that it was conceived in the hypocritical sin of Victors' Justice and the absence of what has come to be expected of procedural due

\footnotetext{
${ }^{12}$ See M. Helal, 'The Crisis of World Order and the Missing Voice of International Law', OpinioJuris, 14 September 2018, available at opiniojuris.org/2018/09/14/the-crisis-of-world-order-and-the-missing-voice-of-international-law/; M. Helal, 'The Crisis of World Order and the Constitutive Regime of the International System', (forthcoming 2019) 46 Florida State University Law Review, Ohio State Public Law and Legal Theory Working Paper Series No. 459, available at papers.ssrn.com/ sol3/papers.cfm?abstract_id=3247645; P. Mishra, 'The Globalization of Rage: Why Today's Extremism Looks Familiar', (2017) 95 Foreign Affairs 46; E. Luce, The Retreat of Western Liberalism (2017); H. Kissinger, World Order (2014).

${ }^{13} \mathrm{See}$, for example, the recent seminar, 'International Law in a Dark Time', organized by the Erik Castrén Institute of International Law and Human Rights and Peking University Institute of International Law Collaboration Project, available at blogs.eui.eu/ constitutionalism-politics-working-group/cfp-seminar-doctoral-students-junior-researchers-international-law-dark-time/; 2016 ESIL Annual Conference, 'How International Law Works in Times of Crisis', Riga, 8-10 September 2016, available at esil-sedi. $\mathrm{eu} / \mathrm{p}=1060$ \&lang=fr; ESIL Research Forum, 'International Law in Times of Disorder and Contestation', Jerusalem, 28 February-1 March 2018, available at esil-sedi.eu/?p=3592\&lang=fr; W. van Genugten and M. Bulterman, 'Crises: Concern and Fuel for International Law and International Lawyers', (2012) 44 NYIL 3.

${ }^{14}$ See Amsterdam Centre for International Law, 'Contingency in the Course of International Law', 14-16 June 2018, University of Amsterdam, available at acil.uva.nl/content/events/workshops/2018/06/contingency-in-the-course-of-international-law-howinternational-law-could-have-been.html. See also I. Venzke, 'What If? Counterfactual (Hi)Stories of International Law', (2018) 8 Asian Journal of International Law 403.

${ }^{15}$ In the specific context of international criminal law, see T. Krever, 'International Criminal Law: An Ideology Critique', (2013) 26 LJIL 701.

${ }^{16} \mathrm{H}$. Charlesworth, 'International Law: A Discipline of Crisis', (2002) 65 Mod.L.Rev. 377. See also B. Authers and H. Charlesworth, 'International Human Rights Law and the Language of Violence' (2013) Regnet Research Paper No. 2013/ 18, available at papers.ssrn.com/sol3/papers.cfm?abstract_id=2364212.

${ }^{17} \mathrm{H}$. Charlesworth, supra note 17 , at 377.

${ }^{18}$ E. Bikundo, 'Saving Humanity from Hell: International Criminal Law and Permanent Crisis', (2013) 44 NYIL 89.

${ }^{19}$ See R. Koselleck, 'Crisis', (2006) 67 Journal of the History of Ideas 357.
} 
process. However, the fundamental point remains: from crisis came progress in the international legal order.

A similar story attaches to the establishment of the ad hoc Tribunals for the former Yugoslavia and Rwanda. The dominant narrative is one of a resurrection and restatement of faith in the international legal order and the notion of supra-national criminal justice following the ending of the decades-long dark age of the Cold War and the guilt-ridden introspection of the international community following its failure to intervene effectively to prevent atrocities witnessed by a global audience. ${ }^{20}$ Amid clichéd cries of 'never again', the violent fallout from the collapse of the Soviet Union on the Balkans, and the murderous, genocidal, instability of the African Great Lakes region, international criminal justice became synonymous with a sense of global consciousness and cosmopolitan progress. ${ }^{21}$ International criminal justice and the purported 'end of history' went hand-inhand. In the eyes of the West - particularly the United States - when staring down the barrel of crises, recourse to international criminal justice mechanisms quickly became a panacea for the functional paralysis of the structures of global peace and security. ${ }^{22}$

By the mid-to-late 1990s, Western faith in the potential of international criminal justice was evangelical, ${ }^{23}$ and drove the crusade that culminated in the signing of the Rome Statute of the ICC in July 1998. With the establishment of the ICC, the purported permanence of the commitment of global justice was formally consecrated and made flesh; 'a gift of hope', 24 'a utopian ideal had become a real and tangible reality which would, from that point onwards, need to be combined with international relations'. ${ }^{25}$ However, from the moment of its creation, the ICC has struggled with the immensity of the expectations placed on its shoulders by its founding congregation. Its mandate was framed as diffuse and all encompassing; preventative, deterrent, punitive, restorative and reconciliatory amongst others. ${ }^{26}$ It was hailed as the messiah and expected to perform miracles as a matter of routine. It is not surprising therefore that it would not be long before its mortality would be exposed and doubt and scepticism would become a more dominant feature of the dialectic.

That global crises have driven the development of international criminal law is a recurring trope of the mainstream historical narrative. There is a clear sense of attachment to the global crises that spurred the emergence of the discipline. Such an attachment is far from unique in international legal scholarship. In this respect, it is worth recalling Charlesworth's observation that:

a parallel can be drawn between the international law [and in this instance, the international criminal law] attachment to crises and the way that traditional forms of history have concentrated on "great men". ${ }^{27}$

However, right now international criminal scholarship is less frequently concerned with international criminal law's ability to respond to global crises, but rather is increasingly focused on the crisis of legitimacy critique that has ensnared the discourse. ${ }^{28}$ Some 20 years after the signing of the Rome Statute, international criminal justice lurches from one apparent catastrophe to

\footnotetext{
${ }^{20} \mathrm{G}$. Bass, Stay the Hand of Vengeance (2002), at 203.

${ }^{21}$ M. Mutua, 'Never Again: Questioning the Yugoslav and Rwanda Tribunals', (1997) Temple International and Comparative Law Journal 167.

${ }^{22} \mathrm{~F}$. Mégret, 'Justice in Times of Violence', (2003) 14 EJIL 327, at 334: referring to international criminal law as a 'palliative to sovereign failure'.

${ }^{23}$ D. Koller, 'The Faith of the International Criminal Lawyer', (2008) 40 N.Y.U.J.Int'l Law \& Pol. 1019.

${ }^{24}$ UN Secretary General, 'Establishing International Criminal Court will be fitting way to inaugurate new millennium', Press Release, UN. Doc. SG/SM/6895, 16 February 1999, available at www.un.org/press/en/1999/19990216.sgsm6895.html.

${ }^{25}$ Speech of the President of the Assembly of States Parties, Mr Sidiki Kaba, $15^{\text {th }}$ session of the Assembly of States Parties, 16 November 2016, available at asp.icc-cpi.int/iccdocs/asp_docs/ASP15/ASP15-Opening-Statement-PASP-ENG.pdf.

${ }^{26}$ See M. Damaška, 'What is the Point of International Criminal Justice?', (2008) 83 Chi-Kent L.Rev. 329.

${ }^{27} \mathrm{H}$. Charlesworth, supra note 17 , at 388.

${ }^{28}$ See S. Vasiliev, 'Between International Criminal Justice and Injustice: Theorising Legitimacy', in N. Hayashi and C.M. Bailliet (eds.), The Legitimacy of International Criminal Tribunals (2017), at 66. See generally Hayashi and Bailliet, ibid.
} 
another, experiencing not a moment of crisis, but rather a persistent state of crisis. The permanent state of emergency of international criminal justice has been normalized to the extent that, as Sergey Vasiliev has put it, '[t]he language of crisis is now a cliché, ${ }^{29}$ with it rarely being utilized as a meaningful analytical tool. ${ }^{30}$ With crisis normalized, the potential for change and development has been replaced with a defensive posture from the project's supporters. The crisis discourse as it has been out played in the media, the commentariat and in scholarship, has become exhausting. One way to emerge from this sense of 'crisis fatigue' is to accept that, however nostalgic the historical narrative, the international criminal justice project has never existed blissfully free of internal or external crises of one form or another; that crisis far from being the exception has in fact been the norm all along. To continue to contend otherwise is to condemn the discourse to 'a sort of disciplinary hamster wheel' ${ }^{31}$

Nevertheless, the cumulative effect of a number of recent developments has left international criminal justice, and in particular the ICC, in an exceptionally vulnerable state. Between state withdrawals from the Rome Statute and the erosion of African Union support for and co-operation with the ICC, the resurgence in hostile, overtly aggressive rhetoric from the United States towards the Court, ${ }^{32}$ and a pervasive sense of underperformance and ineffectiveness embodied in the collapse of high-profile cases and the issuance of controversial acquittal judgments, the ICC and the international criminal justice project generally has rarely had to navigate stormier seas. ${ }^{33}$ Over the course of 2018 it was impossible to ignore the wealth of mainstream attention given to commemorating the twentieth anniversary of the signing of the Rome Statute, the entry into force of the crime of aggression, as well as the legacy of the Yugoslav Tribunal following the conclusion of its mandate on 31 December 2017. There has been no shortage of international conferences, journal special issues, edited collections, and blog-posts, dedicated to examining where international criminal justice finds itself as it enters the third decade after Rome. There is great potential for growth in this moment of self-reflection but it can only be realized if the process is genuine, honest, and takes on board discomforting perspectives offered by voices other than those of the mainstream.

\section{Crisis and progress}

In the last Editorial by a member of the International Criminal Courts and Tribunals section of LJIL, Elies van Sliedregt noted the growing sense of disillusionment and discontentment with the international criminal justice project. She emphasized that in this context:

ICL scholarship should be more than just dissecting legal provisions and commenting on judgments. ICL needs scholarship that tests assumptions underlying the international

\footnotetext{
${ }^{29}$ See Vasiliev, supra note 8.

${ }^{30}$ Ibid., Vasiliev identifies two notable exceptions in this regard: M.V.S. Sirleaf, 'Regionalism, Regime Complexes and the Crisis in International Criminal Justice', (2016) 54 Colum.J.Transnat'l.L. 699; and S. Kendall, 'Critical Orientations: A Critique of International Criminal Court Practice’, in C. Schwöbel (ed.), Critical Approaches to International Criminal Law (2014).

${ }^{31}$ D. Kennedy, 'When Renewal Repeats: Thinking Against the Box', (2000) 32 N.Y.U.J.Int'l Law \& Pol. 335, at 407. A similar argument is made by Charlesworth, supra note 17, at 391.

${ }^{32}$ For example: 'As far as America is concerned, the ICC has no jurisdiction, no legitimacy, and no authority. The ICC claims near-universal jurisdiction over the citizens of every country, violating all principles of justice, fairness, and due process. We will never surrender America's sovereignty to an unelected, unaccountable, global bureaucracy', H.E. Donald Trump, 'Address by the President of the United States of America', $73^{\text {rd }}$ Session of the United States General Assembly Annual General Debate, New York, 25 September 2018, available at gadebate.un.org/sites/default/files/gastatements/73/us_en.pdf. 'We will not cooperate with the ICC. We will provide no assistance to the ICC. We will not join the ICC ... We will let the ICC die on its own. After all, for all intents and purposes, the ICC is already dead to us', J. Bolton, 'Speech to the Federalist Society', Al Jazeera, 10 September 2018, available at www.aljazeera.com/news/2018/09/full-text-john-bolton-speech-federalist-society-180910172828633.html.

${ }^{33}$ While there have been frequent cries of 'crisis' from the both the Court's supporters and detractors, little attention has been given to contemplating the geopolitical fallout should the Court ever actually succumb to crises.
} 
criminal justice system, if only to temper expectations. It needs scholarship that engages with those pushing a normative, idealist or political agenda. It needs scholarship that studies the system in its context and uncovers the political and social reality. ${ }^{34}$

This call for the pursuit of more sophisticated, considered, and interdisciplinary methodologies within international criminal scholarship could not have been more timely. Some two years on from van Sliedregt's Editorial, there are some indications that her cry has been heeded on the margins of international criminal justice scholarship, but it is far from having been consistently or comprehensively answered by the mainstream.

Amongst the most striking, but entirely positive, take-aways from international criminal justice's festering crisis of legitimacy has been the identification and admission of the weaknesses and myopia of the paradigms, and their consequent theoretical lenses and methodologies, underpinning mainstream international criminal justice scholarship. ${ }^{35}$ Mainstream scholarship in the field has traditionally been overwhelmingly doctrinal. As Michelle Burgis-Kasthala has commented:

[T] he dominant paradigm informing ICL scholarship is a positivist, liberal one which favours doctrinal writing or at most, discourse analysis about the normative underpinnings of the ICL project. Empirical research, for example as found in the social sciences, is marginal for most legal research because normative analysis tends to displace explanation, prediction or analyses of human behaviour. ${ }^{36}$

She notes further that, 'most ICL work contains no explicit statement on methodology and when they do, it is far from systematic', ${ }^{37}$ and that 'often there is no distinction between scholarship on ICL and ICL scholarship in support of the field itself. ${ }^{38}$

Burgis-Kasthala's observations are inescapable but there is evidence that, although there is a long way to go, the roots of more advanced interdisciplinary methodologies are beginning to get a tentative foothold in mainstream international criminal justice scholarship. This advancement has been motivated by deeper engagement with the crises of legitimacy and identity that attach both to the establishment and practices of international criminal justice institutions, and the manner in which international criminal justice scholarship has gone about addressing them. In his Editorial in 2012, Carsten Stahn remarked on the emergence of empirical research on the goals and effects of international criminal trials, but noted the prevailing 'tension between "faith" (i.e., belief in the value and worthiness of the project) and "facts" (i.e., actual and demonstrable record). ${ }^{39}$ He made a plea for 'a greater degree of realism', the adoption of more advanced methodologies of assessment, and 'a better scientific grounding of the discipline' ${ }^{40}$ Acknowledging the need to move away from the faith-based, liberal paradigm, and its attendant doctrinal impulses, towards legal realism, critique, and empiricism, suggests that the onset of the international criminal justice project's crisis of legitimacy has assisted in elevating the sophistication of international criminal scholarship; in other words, institutional, political, and legal crises have spurred on scholarly progress.

\footnotetext{
${ }^{34}$ See van Sliedregt, supra note 5 , at 5 .

${ }^{35}$ M. Burgis-Kasthala, 'Scholarship as Dialogue? TWAIL and the Politics of Methodology', (2016) 14 JICJ 921; F. Mégret, 'What Sort of Global Justice is "International Criminal Justice"?', (2015) 13 JICJ 77.

${ }^{36}$ See Burgis-Kasthala, supra note 36, at 927.

${ }^{37}$ Ibid., at 929. Burgis-Kasthala does note a number of exceptions in this regard, namely: A. Smeulers et al., 'The Selection of Situations by the ICC: An Empirically Based Evaluation of the OTP's Performance', (2015) 15 Int.C.L.R. 1; and L. Sadat, 'Crimes Against Humanity in the Modern Age', (2013) 107 AJIL 334.

${ }^{38}$ Ibid., at 928 .

${ }^{39}$ See Stahn, supra note 5 , at 254.

${ }^{40}$ Ibid., at 257. See also van Sliedregt, supra note 5, at 8: 'ICL, in pursuing original scholarship and advancing the field as a whole, can draw on and take inspiration from legal realism'.
} 
One obvious example of this is the amplified register of critique and socio-legal research in scholarship's response to, and consideration of, the apparently interminable impasse in the relationship between the ICC and African states. ${ }^{41}$ Initiated by the issuance of the arrest warrant against Sudanese President Omar Al-Bashir in 2009, but exacerbated by the Court's near exclusive focus on crimes committed on the continent of Africa - in particular the attempted (but ultimately failed) prosecutions of Libyan leader Muammar Gaddafi, and Kenyan President Uhuru Kenyatta and his Vice-President William Ruto - the ICC 'Africa Crisis' reached its nadir in 2016 with the announcement by South Africa, Burundi and The Gambia of their intention to withdraw from the ICC. ${ }^{42}$ The rhetoric of the disaffected states (supported by the African Union ${ }^{43}$ ) classed the ICC as an institution of neo-colonial oppression; an 'International Caucasian Court', ${ }^{44}$ set up expressly for the 'persecution and humiliation of people of colour, especially Africans'. ${ }^{45}$ While the crisis continues to be dramatically played out in the political and legal spheres, ${ }^{46}$ it has created a space within which international criminal justice's inherent selectivity, as well as its historical links with hegemonic power and structural inequalities, could begin to be explored in mainstream scholarship. ${ }^{47}$ It has also created space within which to examine the lived experiences of international criminal justice. $^{48}$

Particularly exciting in this respect has been the increasing prominence of a TWAIL critique of international criminal justice. ${ }^{49}$ A recent symposium in the Journal of International Criminal Justice, entitled 'Third World Approaches to International Criminal Law', posed a series of heretofore under-examined questions such as:

What does it mean to think about international [criminal] law's norms, rules, institutions and procedures through the frames of the colonial past or imperial present? What biases,

\footnotetext{
${ }^{41}$ See generally K. Clarke, A. Knotterus and E. De Volder, Africa and the ICC: Perceptions of Justice (2016); C. Jalloh and I. Bantekas, The International Criminal Court and Africa (2017).

${ }^{42}$ For an overview see M. Ssenyonjo, 'State Withdrawals from the Rome Statute of the International Criminal Court: South Africa, Burundi and The Gambia', in Jalloh and Bantekas, ibid., at 214.

${ }^{43}$ See the AU 'Withdrawal Strategy Document', available at www.hrw.org/sites/default/files/supporting_resources/icc withdrawal_strategy_jan._2017.pdf.

${ }^{44}$ See S. O’Grady, 'Gambia: The ICC Should be Called the International Caucasian Court', Foreign Policy, 26 October 2016.

${ }^{45}$ Ibid.

${ }^{46} \mathrm{Particularly}$ in the context of the Al Bashir case and the ongoing issue of the relationship between the Rome Statute and the applicability of head of state immunity. See Prosecutor v. Omar Hassan Ahmad Al Bashir, Revised Order on the Conduct of the Hearing Before the Appeals Chamber in the Jordan Referral re Al-Bashir Appeal, Case No. ICC-02/05-01/09 OA2, 30 August 2018; Media Advisory, 'Al Bashir Case: ICC Appeals Chamber Hearing Submission on Legal Matters Raised by Jordan from 10-14 September', ICC, available at www.icc-cpi.int/Pages/item.aspx?name=ma232.

${ }^{47}$ For a small selection of this burgeoning field see, for example, Clarke, Knotterus and De Volder, supra note 42; S. Nouwen and W. Werner, 'Doing Justice to the Political: The International Criminal Court in Uganda and Sudan', (2010) 21 EJIL 942; A. Tiemessen, 'The International Criminal Court and the Politics of Prosecutions', (2014) 18 IJHR 444; W. Kaleck, Double Standards: International Criminal Law and the West (2015); A. Kiyani, 'Group-Based Differentiation and Local Repression: The Custom and Curse of Selectivity’, (2016) 14 JICJ 939; Krever, supra note 16; C. Schwöbel (ed.), Critical Approaches to International Criminal Law (2014).

${ }^{48}$ See, for example, S. Nouwen, “'As You Set Out for Ithaka”: Practical, Epistemological, Ethical, and Existential', (2014) 27 LJIL 227; S. Kendall and S. Nouwen, 'Representational Practices at the International Criminal Court: The Gap Between Juridified and Abstract Victimhood', (2013) 76 Law and Contemporary Problems 235; K. Clarke, Fictions of Justice: The International Criminal Court and the Challenge of Legal Pluralism in Sub-Saharan Africa (2009).

${ }^{49}$ See generally the symposium entitled, 'Third World Approaches to International Criminal Law' in (2016) 14 JICJ at 915-1030. Earlier outliers of TWAIL scholarship on international criminal law include: A. Anghie and B.S. Chimni, 'Third World Approaches to International Law and Individual Responsibility', (2003) 2 Chinese Journal of International Law 77; C. Jalloh, 'Regionalizing International Criminal Law?', (2009) 9 Intl.C.L.R. 445; and O.C. Okafor and U. Ngwaba, 'The International Criminal Court as a “Transitional Justice” Mechanism in Africa: Some Critical Reflections', (2015) 9 International Journal of Transitional Justice 90.
} 
blind spots, political motives and rhetorical tropes emerge from the ways in which international criminal justice mechanisms navigate the racial and socio-economic cleavages that persist between North and South ${ }^{50}$

The symposium sought not to be reflexively critical, but rather to identify possibilities and alternatives to that which it problematizes, and new avenues of exploration for scholars working outside of the TWAIL tradition'.51 The symposium's invitation for further interdisciplinary collaboration and dialogue should be echoed and replicated throughout the international criminal justice discourse.

In this vein collaborations could be deepened with disciplines such as social psychology, criminology, anthropology, feminist theory and international relations. The interaction of diverse disciplinary voices on issues can only lead to enlightened perspectives which offer greater clarity and insight into issues central to the question of international criminal law's legitimacy. If crisis is a product of anxiety then surely the best way to work through those anxieties is to have them expressed openly and reflected on by external actors; in this sense interdisciplinary dialogue can be viewed as a therapeutic exercise.

\section{Drawing the parameters of crises: 'Ordinary' v. 'extraordinary' critique}

The 'crisis of legitimacy' narrative that the African withdrawals fed into is not unique to international criminal justice institutions and can be placed within a growing trend towards sovereign resistance to international courts. ${ }^{52}$ From the ICC, the Southern African Development Community Tribunal and the African Court on Human and Peoples' Rights to the Inter-American Court of Human Rights, the European Court of Justice and the European Court of Human Rights, numerous states have either withdrawn or threatened to withdraw their participation and jurisdictional consent from international courts in recent years. In the current geopolitical climate the reflexive response of the commentariat has been to proclaim the 'backlash' as symptomatic of 'a changed world order prompted by the emergence of a set of new socio-political constellations that share a pronounced scepticism towards universalism'. ${ }^{53}$ Such responses are understandable given the exponential rise in proclamations of sovereign exceptionalism, notable amongst which was Donald Trump's statement to the $73^{\text {rd }}$ Session of the UN General Assembly in September 2018, where he declared that 'America is governed by Americans. We reject the ideology of globalism and we embrace the doctrine of patriotism' 54

There is, however, no straightforward explanation for the alleged decline in support for international courts, nor is there a one-size-fits-all solution to the issue, if indeed a solution is required. ${ }^{55}$ However, the trend has given rise to a burgeoning literature unpacking the dynamics of 'backlash's6 against international courts from a socio-legal and international relations theory

\footnotetext{
${ }^{50}$ A. Kiyani, J. Reynolds and S. Xavier, 'Foreword: Third World Approaches to International Criminal Law', (2016) 14 JICJ 915, at $917-18$.

${ }^{51}$ Ibid., at 918 .

${ }^{52}$ M. Madsen, P. Cebulak and M. Wiebusch, 'Backlash Against International Courts: Explaining the Forms and Patterns of Resistence of International Courts', (2018) 14 International Journal of Law in Context 197.

${ }^{53}$ Ibid., at 198.

${ }^{54}$ See Trump, supra note 33.

${ }^{55}$ See, J. Crawford, 'The Current Political Discourse Concerning International Law', (2018) 81 Mod.L.Rev. 1.

${ }^{56}$ Defined by Henry Lovat as, 'intense and sustained government disapproval of tribunal conduct, accompanied by aggressive steps to resist such conduct and to remove its legal force'. See H. Lovat, 'International Criminal Tribunal Backlash', in K. Heller et al. (eds.), Oxford Handbook of International Criminal Law (forthcoming 2019), available at papers.ssrn.com/sol3/ papers.cfm?abstract_id=3253050. See also contributions to 'Resistence to International Courts - Special Issue', (2018) 14 International Journal of Law in Context, at 193-313.
} 
perspective. This literature has sought to distinguish between 'resistance', 'pushback', and 'backlash', and interestingly to separate 'ordinary critique' from 'extraordinary critique'. ${ }^{57}$ Henry Lovat defines 'ordinary critique' as 'a form of resistance occurring within the playing field of [international courts] and typically concerning specific legal developments in jurisprudence and case-law'. ${ }^{58}$ 'Extraordinary critique' on the other hand, 'goes beyond the ordinary playing field of law and includes a critique of not only law but also that very institution - the court - and its authority' ${ }^{59}$

In the specific context of the ICC, this separation between 'ordinary' and 'extraordinary' critique is a useful lens through which to evaluate the propriety of the crisis label that seems to attach to each and every event that negatively impacts on the legitimacy of the Court in some way. As this Editorial has noted, the crisis narrative has become clichéd and exhausting in international criminal justice commentary and scholarship. Sergey Vasiliev points out, 'there is no hard formula for affixing the "crisis" label to specific events ... "crisis" is not a category of objective reality; it is a matter of perspective and group psychology (or psychoanalysis)" ${ }^{60}$ The apportioning of the crisis label might on the one hand be viewed as a symptom of hypochondria, or on the other hand as an obvious addiction to the adrenaline-infused, endorphin-releasing effects of crisis; after all, we never feel as simultaneously alive or as close to death as we do in the midst of a crisis. Crisis can also act as a rallying cry; "“crises” impart ICL supporters with a therapeutic sense of shared experience. Critical situations are the turning points around which professional and ideological communities consolidate, raising issues of identity and belonging and making their membership more defined' ${ }^{61}$ However, it is also worth recalling in this respect Charlesworth's stinging critique that employing the language of crisis 'encourages international lawyers to cast [themselves] grandly in an heroic mould'. ${ }^{2}$

An appreciation of the distinction between ordinary and extraordinary critique has the potential to promote a more rational, constructive discourse on the issues confronting international criminal justice institutions and international criminal law generally. The fact of the matter is that not every bombastic statement from a government in the headlights of the ICC's jurisdiction gives rise to a full-blown crisis, nor do (partial or complete) judgments of acquittal, or frustrations over the limited number of cases on the Court's docket and the slow pace of proceedings. They can certainly be posited as concerns, setbacks, or evidence of inefficiency and ineffectiveness, but to feed every issue into the crisis narrative merely leads to a spike in blood pressure and the muting of scholarly dialogue. To be clear, I am in no way suggesting that international criminal justice's legitimacy crisis is a figment of the imagination, far from it. Rather, I am merely arguing that the language of crisis should be reserved for accumulated, related, instances of extraordinary critique. The labelling of acts of ordinary critique as yet another phase in the cycle of crisis inevitably results in mainstream scholarship's attention being taken away from the examination of, and engagement with, the theoretical, historical and contemporary foundations of international criminal justice's very real legitimacy crisis. ${ }^{63}$

The impulse of much of mainstream scholarship to fight the latest fire sparked by ordinary critique might be viewed as a straightforward example of displacement behaviour; that is, a means of avoiding facing up to the demons that continue to undermine the legitimacy of international

\footnotetext{
${ }^{57}$ Madsen, Cebulak and Wiebusch, supra note 53, at 197, 199. See also D. Caron and E. Shirlow, 'Dissecting Backlash: The Unarticulated Causes of Backlash and Its Unintended Consequences', in A. Follesdal and G. Ulfstein (eds.), The Judicialization of International Law: A Mixed Blessing? (2018), 159; K. Alter, J. Gathii and L. Helfer, 'Backlash Against International Courts in West, East and Southern Africa: Causes and Consequences', (2016) 27 EJIL 293; Madsen, Cebulak and Wiebusch, supra note 53.

${ }^{58}$ Madsen, Cebulak and Wiebusch, supra note 53, at 199.

${ }^{59}$ Ibid., at 199.

${ }^{60}$ See Vasiliev, supra note 8 , at 8.

${ }^{61}$ Ibid., at 12 .

${ }^{62}$ See Charlesworth, supra note 17 , at 387.

${ }^{63}$ Similar sentiments are expressed by Vasiliev, supra note 8 , at 13.
} 
criminal law, frequently preferring instead to keep its head firmly in the sand. ${ }^{64}$ An example of this is the way in which the twentieth anniversary of the signing of the Rome Statute was reflected on in recent symposia in mainstream journals. Three in particular come to mind, namely: the Journal of International Criminal Justice's symposium, 'The Intention of the Drafters - The ICC at 20'; 65 the International Criminal Law Review's special issue entitled, 'The Rome Statute at Twenty: Enhancing Efficiency and Effectiveness at the International Criminal Court'; 6 and AJIL Unbound's 'Symposium on the Rome Statute at Twenty'. ${ }^{67}$

All three are notable for their focus on various challenges such as: functional performance and the development of various institutional actors and organs; ${ }^{68}$ the means by which efficiency gains can be achieved; procedural lacunae and how they might be addressed; and concerns with regard to the effectiveness of state co-operation. Contributions were dominated by practitioners, including current and former members of the international criminal bench, who outnumbered contributions from scholars by two to one. ${ }^{69}$ All three symposia offer valuable insights and are an undoubted contribution to scholarship; however, they are speaking to a supportive, already converted, congregation. They amount to little more than a reaffirmation of faith. There is acknowledgement of some of the ICC's shortcomings and the frustrations shared by its supporters, but the message is clearly one of 'we can and we will do better'. They also clearly play into the notion of increased managerialism and reform of bureaucracy as tools designed to drive a sense of internal progress and thereby increase the legitimacy of the ICC in the eyes of certain communities, in particular stake-holders. ${ }^{70}$

Reading the symposia, I could not help but question if an opportunity had been wasted for a more inclusive, interdisciplinary, cross-cutting exchange on some of the issues that go to the heart of the legitimacy critique. It is also a clear indication that while interdisciplinary critique has become a more prominent, dare I say, fashionable voice in mainstream international criminal scholarship, it is far from being mainstreamed. This is exactly as it should be since the power of critique lies in its transgressive potential, its refusal to be pigeonholed, and the perspective offered by its externality. ${ }^{71}$

\section{Parting remarks}

This Editorial has offered some reflections on the pervasive and seemingly endless sense of crisis attaching to the contemporary international criminal justice project. It has tried to give a sense of how it has gone from being the protégé of the international legal order to being overwhelmed by expectations, riddled with anxieties, and struggling with its existential legitimacy. The language of crisis has become clichéd, overwrought and counterproductive. Nonetheless, international criminal justice's crisis of legitimacy is unavoidable and has been laid bare by instances of extraordinary

\footnotetext{
${ }^{64}$ More sceptically, it might also be viewed as a tactic of 'deliberate circumvention, muting, and exclusion'. I am grateful to Sergey Vasiliev for this insight. See Vasiliev, supra note 8, at 13. For an account of crisis as distraction, see B. Authers and H. Charlesworth, 'The Crisis and the Quotidian in International Human Rights Law', (2013) 44 NYIL 20, at 28-30.

${ }^{65}$ 'Symposium: The Intention of the Drafters - the ICC at 20', (2018) 16 JICJ at 230-402.

${ }^{66 r}$ 'Special Issue: The Rome Statute at Twenty - Enhancing Efficiency and Effectiveness at the International Criminal Court', (2018) 3 Intl.C.L.R. at 377-575.

${ }^{67}$ 'Symposium on the Rome Statute at Twenty', (2018) 112 AJIL Unbound at 155-86.

${ }^{68} \mathrm{Be}$ it with respect to the Assembly of States Parties, the judiciary, the Office of the Prosecutor; defence counsel, or legal counsel for victims. See supra note 67.

${ }^{69}$ Excluding Forewords, there were a total of 20 contributions to the three symposia; 14 from practitioners, six from scholars.

${ }^{70}$ For an excellent treatment of this, see the article by Richard Clements in this issue of LJIL. R. Clements, 'From Bureaucracy to Management: The International Criminal Court's Internal Progress Narrative', (2019) 32 LJIL doi: 10. 1017/S092215651800064X.

${ }^{71}$ F. Mégret, 'International Criminal Justice: A Critical Research Agenda', in C. Schwöbel (ed.), Critical Approaches to International Criminal Law (2014), at 46; see also Jacobs, supra note 5, at 2.
} 
critique. In this context we cannot ignore the fact that, like the rest of the international legal order, it has felt the impact of the uncertainties and insecurities that have been an inevitable consequence of the current geopolitical landscape and in particular the apparent backlash against international courts. However, the silver lining has been the emergence of a more theoretically and methodologically sophisticated body of international criminal justice scholarship that has sought to unpack and expose the roots of the field's crisis of legitimacy. Crisis has helped to generate the potential for a widening of the scholarly space, however, while progress has been made this potential is yet to be fully realized. It is essential that international criminal scholarship continues to embrace inter- and cross-disciplinarity alongside its rich doctrinal heritage. LJIL, and the International Criminal Courts and Tribunals section specifically, will continue to play its role in facilitating diverse disciplinary exchanges. Such exchanges can only lead to a rich shared discourse even if there will inevitably be occasions of defensiveness, intellectual discomfort, and disagreement as we challenge the validity of the core beliefs that sit at the centre of the amygdala of international criminal justice; this is a small price to pay in the service of the 'eternal rhythm of progress, onward and upward'. ${ }^{72}$

\footnotetext{
${ }^{72}$ See Zweig, supra note 2, at 3.
}

Cite this article: Powderly J (2019). International criminal justice in an age of perpetual crisis. Leiden Journal of International 